\title{
PENGARUH MODEL PEMBELAJARAN PENEMUAN TERBIMBING TERHADAP HASIL BELAJAR SISWA SMP NEGERI 11 KOTA BENGKULU
}

\author{
Bella Trinofita ${ }^{1}$, Agus Susanta ${ }^{2}$, dan Hanifah $^{3}$ \\ ${ }^{1,3}$ Program Studi Pendidikan Matematika, FKIP Universitas Bengkulu, \\ ${ }^{2}$ Program Studi S-2 Pendidikan Dasar, FKIP Universitas Bengkulu \\ Email : ${ }^{1}$ trinovitabella@gmail.com, ${ }^{2}$ unibagus@yahoo.com, ${ }^{3}$ hanifah@unib.ac.id
}

\begin{abstract}
Abstrak
Penelitian ini bertujuan menganalisis pengaruh model pembelajaran penemuan terbimbing terhadap hasil belajar matematika siswa kelas VIII SMP Negeri 11 Kota Bengkulu. Populasi penelitian ini adalah siswa kelas VIII SMP Negeri 11 Kota Bengkulu. Sampel penelitian ini adalah kelas VIII D sebagai kelas eksperimen yang menerapkan model pembelajaran penemuan terbimbing dan kelas VIII E sebagai kelas kontrol yang menerapkan strategi pembelajaran ekspositori. Teknik pengumpulan data dengan menggunakan instrumen tes. Untuk analisis data instrumen tes menggunakan uji-t dengan data berdistribusi normal dan homogen. Berdasarkan hasil penelitian diperoleh nilai rata-rata hasil belajar siswa yang diajar dengan menggunakan model pembelajaran penemuan terbimbing lebih tinggi dibandingkan dengan nilai rata-rata hasil belajar siswa yang diajar dengan strategi pembelajaran ekspositori. Nilai rata-rata hasil belajar siswa kelas eksperimen adalah 80,91 dan nilai rata-rata hasil belajar siswa kelas kontrol adalah 59,41. Hal ini sesuai dengan hasil uji hipotesis nilai $t_{\text {hitung }}=6,463>$ nilai $\mathrm{t}_{\text {tabel }}=2,000$ dengan $\alpha=5 \%$. Maka $\mathrm{H}_{0}$ ditolak sehingga dapat disimpulkan bahwa ada pengaruh model pembelajaran penemuan terbimbing terhadap hasil belajar siswa kelas VIII SMP Negeri 11 Kota Bengkulu.
\end{abstract}

Kata Kunci: hasil belajar, penemuan terbimbing, strategi ekspositori

\begin{abstract}
The aim of the research is to know how to the effect of guided discovery learning model to study's result student class VIII SMP Negeri 11 Kota Bengkulu. Population of this research is students class VIII SMP Negeri 11 Kota Bengkulu. Sample of this research is student class VIII D for the experiment class apply to guided discovery learning model and class VIII E for control class apply to expository learning strategy. The technique data collection is instrument test. To analyze the instrument test data using the formula t-test with normal distribution data and homogen. Based on the research value the average study's result experiment class higher than the average study's result control class. The average of experimental class is 80,91 and the average of control class is 59,41. This is consistent with the value hypothesis test result valuet $=6,463<$ value table $=2,000$ with $\alpha=5 \%$. Then $H_{0}$ is rejected so that it can be concluded that there is the effect of guided discovery learning model to study's result student class VIII SMP Negeri 11 Kota Bengkulu.
\end{abstract}

Keyword: study's result, guided discovery, expository strategy

\section{PENDAHULUAN}

Matematika merupakan ilmu universal yang mendasari perkembangan teknologi modern, mempunyai peran penting dalam berbagai disiplin (Depdiknas, 2006). Matematika sebagai salah satu mata pelajaran yang diajarkan pada setiap jenjang pendidikan mulai dari sekolah dasar hingga perguruan tinggi. Sehingga sangatlah penting bagi siswa untuk memahami pelajaran matematika secara benar.

Hasil wawancara peneliti dengan beberapa siswa SMP Negeri 11 Kota Bengkulu,

Trinofita, Susanta, Hanifah

Pengaruh Model Pembelajaran Penemuan Terbimbing terhadap Hasil Belajar Siswa SMP Negeri 11

Kota bengkulu 
ditemukan permasalahan pembelajaran matematika adalah banyaknya siswa yang menganggap matematika sebagai pelajaran yang sulit. Selain itu, siswa cenderung tidak mengetahui manfaat nyata dari matematika dalam kehidupan sehari-hari yang mengakibatkan siswa malas untuk mempelajari matematika. Hasil observasi peneliti selama Magang 3 di SMP Negeri 11 Kota Bengkulu, diketahui beberapa masalah yang terkait dengan proses pembelajaran matematika, yaitu hasil belajar matematika siswa pada ranah kognitif masih tergolong rendah karena masih banyak siswa mendapatkan hasil belajar dibawah Kriteria Ketuntasan Minimal (KKM) yang ditentukan yaitu 75 .

Berdasarkan hasil observasi memperlihatkan cara mengajar guru yang masih menggunakan model pembelajaran yang hanya berpusat pada guru, guru mendominasi kegiatan belajar mengajar, definisi dan rumus diberikan oleh guru, penemuan rumus dan pembuktian dalil dibuktikan sendiri oleh guru dan contoh-contoh soal diberikan dan dikerjakan sendiri oleh guru, sehingga siswa hanya meniru cara kerja dan cara penyelesaian yang dilakukan oleh guru. Seharusnya guru membimbing siswa untuk menemukan konsep matematis, dan membuat siswa terlibat langsung dalam menemukan konsep matematis. Sehingga siswa akan lebih mudah memahami pelajaran sesuai dengan bahasa mereka sendiri. Kegiatan seperti ini yang seharusnya dilakukan siswa sehingga dapat membangun dan menumbuhkan kemampuan pemahaman konsep matematis pada siswa.

Ketika melakukan kegiatan belajar mengajar, guru hendaknya menerapkan suatu model pembelajaran yang melibatkan siswalangsung dalam proses pembelajaran. Mencermati hal tersebut, salah satu cara untuk menciptakan pengajaran matematika yang dapat melibatkan siswa dan menumbuhkan pemahaman konsep siswa adalah melalui penggunaan model pembelajaran penemuan terbimbing.
Model pembelajaran penemuan terbimbing merupakan model pembelajaran yang di mana siswa dihadapkan dengan situasi di mana ia bebas untuk mengumpulkan data, membuat dugaan, mencoba-coba (trial and error), mencari dan menemukan keteraturan (pola), menggeneralisasi atau menyusun rumus beserta bentuk umum, membuktikan benar tidaknya dugaannya itu menurut Markaban (2008). Sedangkan menurut Hosnan (2016) Model penemuan terbimbing adalah salah satu model pembelajaran yang dapat melibatkan langsung siswa secara aktif dimana guru memberi siswa contoh-contoh topik spesifik dan memandu siswa untuk memahami topik. Artinya model penemuan terbimbing menjadikan siswa lebih aktif terlibat dalam menyelidiki, menginvestigasi, mencoba dan akhirnya menemukan sendiri konsep matematika yang dimaksud.

Pembelajaran penemuan merupakan metode pembelajaran kognitif yang menuntut guru lebih kreatif menciptakan situasi yang dapat membuat peserta didik belajar aktif menemukan pengetahuan sendiri (Abdullah, 2014; 98). Hal ini memungkinkan siswa untuk lebih menguasai materu yang disampaikan di kelas.

Berdasarkan uraian di atas, maka peneliti melakukan penelitian yang bertujuan untuk menganalisis pengaruh Pembelajaran Penemuan Terbimbing Terhadap Hasil Belajar Siswa Kelas VIII SMP Negeri 11 Kota Bengkulu

\section{METODE PENELITIAN}

Jenis penelitian yang digunakan dalam penelitian ini adalah quasi experiment (eksperimen semu). Penelitian ini dilaksanakan SMP Negeri 11 Kota Bengkulu.Populasi dalam penelitian ini yaitu siswa kelas VIII SMP Negeri 11 Kota Bengkulu tahun ajaran 2017/2018. Pada penelitian ini, teknik pengambilan sampel yang digunakan adalah purposive sampling. Purposive sampling adalah teknik penentuan sampel dengan pertimbangan tertentu (Sugiyono, 2017: 67). Penentuan sampel pada penelitian ini dengan mengambil dua kelas yang

Trinofita, Susanta, Hanifah

Pengaruh Model Pembelajaran Penemuan Terbimbing terhadap Hasil Belajar Siswa SMP Negeri 11

Kota bengkulu 
diajar oleh guru matematika yang sama dan dengan mempertimbangkan kemampuan awal yang relatif sama. Satu kelas yaitu kelas VIII D sebagai kelas eksperimen dan kelas VIII E sebagai kelas kontrol.

Instrumen yang digunakan dalam penelitian ini adalah tes. Posttest diberikan pada subjek penelitian pada akhir proses pembelajaran. Tes yang diberikan kepada siswa terlebih dahulu diujicobakan di kelas uji coba dan dianalisis untuk melihat kevalidan soal, reliabilitas soal, daya beda soal dan taraf kesukaran soal. Soal disusun berdasarkan kisi-kisi yang telah disusun sebelumnya, skor yang diberikan kepada siswa sesuai dengan rubrik penilaian hasil belajar siswa.

Untuk menguji apakah hipotesis yang diajukan diterima atau ditolak maka data yang diperoleh akan dianalisis menggunakan uji t, namun sebelum itu terlebih dahulu dilakukan uji normalitas dan uji homogenitas sebagai prasyarat uji-t.

\section{HASIL DAN PEMBAHASAN \\ Hasil Penelitian}

Penelitian dilaksanakan mulai dari tanggal 29 Maret dan selesai pada tanggal 9 Mei 2018 di SMP Negeri 11 Kota Bengkulu. Sebelum memulai penelitian, peneliti menyiapkan perangkat pembelajaran yang dibutuhkan selama penelitian berlangsung, yaitu soal posttest, lembar soal dan LKPD untuk kelas eksperimen. Posttest sebelum digunakan, terlebih dahulu divalidasi oleh dua orang validator ahli kemudian diujicobakan di kelas uji coba yakni kelas VIII A SMP Negeri 11 Kota Bengkulu yang diikuti oleh 32 siswa.

Pembelajaran pada kelas eksperimen menggunakan model pembelajaran penemuan terbimbing sedangkan pada kelas kontrol menggunakan strategi pembelajaran ekspositori. Tes dilakukan pada kelas eksperimen dan kelas kontrol setelah diberikan perlakuan sebanyak enam kali pertemuan dengan menggunakan instrumen tes bentuk uraian sebanyak 8 soal.
Pertemuan pertama kelas eksperimen, materi yang dipelajari siswa adalah volume kubus. Pada kegiatan pertama siswa diminta untuk mengamati informasi yang ada pada LKPD (tahap simulasi). Selanjutnya tahap identifikasi masalah, siswa mengidentifikasi pertanyaan-pertanyaan yang muncul sesuai atau tidak dengan informasi yang ada pada tahap simulasi, jika ada yang kurang siswa bisa menambahkan pertanyaan baru. Tahap mengumpulan data yaitu siswa mengumpulkan data atau informasi dari buku pelajaran matematika yang dimiliki siswa tentang volume kubus yang dapat membantu siswa menjawab pertanyaan yang telah siswa buat. Selanjutnya setelah data atau informasi di dapat, siswa melakukan tahap mengolah data untuk menemukan konsep volume kubus. Tahap verifikasi data untuk membuktikan hipotesis yang telah dibuat siswa. Siswa membuat kesimpulan lalu menyampaikan hasil kegiatan kelompok di depan kelas. Untuk pertemuan kedua dan seterusnya juga dilakukan dengan tahap belajar yang sama dengan materi yang dipelajari yakni volume balok, volume prisma, volume limas dan luas permukaan limas.

Pertemuan pertama untuk kelas kontrol sama dengan kelas kelas eksperimen yaitu materi volume kubus. Guru menjelaskan materi pada siswa, memberikan contoh soal dan menjelaskan cara penyelesaiannya. Guru memberi kesempatan kepada siswa untuk mecatat penjelasan yang sudah dijelaskannya dan menanyakan hal-hal yang belum jelas. Setelah itu siswa menerima soal-soal latihan dan mengerjakannya, saat guru mengajar menggunakan strategi ekspositori siswa cenderung pasif, hanya ada beberapa siswa yang berperan aktif yaitu bertanya dan menjawab pertanyaan guru.

Pada saat proses penelitian berlangsung, siswa pada kelas eksperimen yang belajar dengan menggunakan model pembelajaran penemuan terbimbing memahami materi pelajaran lebih baik. Hal ini disebabkan dalam 
model pembelajaran penemuan terbimbing ini siswa dikelompokkan secara heterogen, kemudian siswa dituntut bekerja sama dalam kelompoknya. Hasil yang lebih baik pada kelas eksperimen ini disebabkan oleh siswa lebih termotivasi dalam belajar matematika dengan menggunakan model pembelajaran penemuan terbimbing. Siswa mampu menyusun, memproses, mengorganisir dan menganalisis data yang disajikan guru. Dalam hal ini, bimbingan guru dapat diberikan sejauh yang diperlukan saja. Bimbingan ini sebaiknya mengarahkan siswa untuk melangkah kearah yang hendak dituju, melalui pertanyaanpertanyaan atau LKPD.

Di akhir proses pembelajaran, siswa diberikan posttest hasil belajar untuk mengukur kemampuan akhir siswa. Berdasarkan analisis hasil penelitian, diperoleh bahwa hasil belajar matematika pada kelas eksperimen lebih tinggi dari hasil belajar matematika pada kelas kontrol, dengan nilai rata-rata kelas eksperimen adalah 80,91 dan nilai rata-rata kelas kontrol adalah 59,41. Pada kelas eksperimen dari 33 orang siswa yang mengikuti posttest terdapat 25 orang siswa yang memiliki nilai diatas kriteria ketuntasan minimal (KKM), hal ini dapat diartikan bahwa $75,75 \%$ nilai posttest siswa mencapai KKM. Sedangkan pada kelas kontrol dari 29 orang siswa yang mengikuti posttest hanya 6 orang siswa yang memiliki nilai diatas $\mathrm{KKM}$, hal ini dapat diartikan bahwa nilai posttest siswa yang mencapai KKM hanya $20,69 \%$.

\section{Pembahasan}

Penerapan model pembelajaran penemuan terbimbing pada kelas eksperimen mempengaruhi hasil belajar siswa, karena siswa mengalami sendiri proses menemukan sehingga siswa benar-benar memahami bahan pelajaran. Menemukan sendiri menimbulkan rasa puas. Kepuasan batin ini mendorong ingin melakukan penemuan lagi sehingga minat belajarnya meningkat. Selain itu, model pembelajaran penemuan terbimbing membuat siswa memiliki pengalaman sendiri dalam menjawab masalah matematika melalui diskusi kelompok yang tidak dialami oleh kelas kontrol.

Hasil dan pemaparan yang diperoleh di atas relevan dengan penelitian yang dilakukan oleh Renita, dkk (2017), yaitu setelah kedua kelas diberikan perlakuan berbeda, yakni menggunakan model pembelajaran penemuan terbimbing pada kelas eksperimen dan pembelajaran konvensional pada kelas kontrol. Hasil posttest menunjukkan bahwa kemampuan pemahaman konsep dengan model penemuan terbimbing lebih tinggi dari kemampuan pemahaman konsep dengan pembelajaran konvensional, sehingga rata-rata hasil belajar kelas yang menggunakan model pembelajaran penemuan terbimbing lebih tinggi dari rata-rata hasil belajar kelas yang menggunakan pembelajaran konvensional. Setiawan (2017) menunjukkan bahwa rata-rata hasil belajar dengan model penemuan terbimbing lebih tinggi dari rata-rata hasil belajar dengan pembelajaran konvensional. Hasil penelitian Wisnawati, dkk (2014) menunjukkan bahwa kemampuan memecahkan masalah matematika dengan model penemuan terbimbing lebih tinggi dari kemampuan memecahkan masalah matematika dengan pembelajaran konvensional, sehingga rata-rata hasil belajar kelas yang menggunakan model pembelajaran penemuan terbimbing lebih tinggi dari rata-rata hasil belajar kelas yang menggunakan pembelajaran konvensional. Hasil penelitian yang dilakukan oleh Apriani, Fitri Pratiwi, 2014; Purwatiningsi, 2013 juga menunjukkan adanya pengaruh model pembelajaran penemuan terbimbing terhadap peningkatan hasil belajar.

\section{PENUTUP \\ Kesimpulan}

Hasil penelitian ini menunjukkan bahwa ada pengaruh model pembelajaran penemuan terbimbing terhadap hasil belajar siswa kelas VIII SMPN 11 Kota Bengkulu. Berdasarkan hasil analisis data menggunakan uji-t, diperoleh nilai rata-rata pada kelas eksperimen sebesar 80,91 dan nilai rata-rata pada kelas kontrol 
sebesar 59,41, dengan thitung $=6,463$ dan ttabel $=2,000$ maka nilai $t_{\text {hitung }}>t_{\text {tabel }}$ pada taraf nyata $\alpha=0,05$ dengan $\mathrm{dk}=60$ berarti $\mathrm{H}_{0}$ ditolak dan $\mathrm{H}_{1}$ diterima, dimana hasil belajar siswa yang menggunakan model pembelajaraan penemuan terbimbing lebih tinggi dari hasil belajar siswa yang menggunakan strategi pembelajaran ekspositori di kelas VIII SMPN 11 Kota Bengkulu.

\section{Saran}

Berdasarkan hasil penelitian ini, dapat dikemukakan saran-saran sebagai berikut:

1. Untuk mencapai hasil belajar yang maksimal disarankan agar guru matematika terus berlatih merumuskan dan memberikan permasalahan-permasalahan kontekstual yang menarik untuk dipecahkan oleh siswa.

2. Untuk menerapkan model pembelajaran penemuan terbimbing, sebaiknya guru memberi umpan balik terhadap siswa agar diketahui apakah seluruh siswa telah dapat memahami materi dengan model pembelajaran penemuan terbimbing.

3. Untuk kegiatan menyimpulkan apabila siswa kesulitan menyusun dan menyatakan kesimpulan dengan kalimat yang jelas dan mudah dipahami, sebaiknya guru mengarahkan siswa untuk membaca referensi lain yaitu buku pelajaran matematika

\section{DAFTAR PUSTAKA}

Abdullah. (2014). Pembelajaran Saintifik Untuk Implementasi Kurikulum 2013. Jakarta : PT Bumi Aksara

Afni, Renita Nur dkk. (2017). Pengaruh Model Pembelajaran Penemuan Terbimbing Terhadap Kemampuan Pemahaman Konsep Matematis Siswa Kelas VIII SMP N 2 Rambah Hilir. Jurnal Mahasiswa S-1 Pendidikan Matematika, (online), Vol. 3, No. 1, (https://ejournal.upp.ac.id, diakses 25 Januari 2018).

Apriani, Fitri Pratiwi. (2014). Pengaruh Penggunaan Model Discovery Learning
Dengan Pendekatan Saintifik Terhadap Keterampilan Berpikir Kritis Siswa SMA. Jurnal pendidikan dan Pembelajaran Untan Vol 3 (1), 2014.

Depdiknas. (2006). Peraturan Menteri Pendidikan Nasional Republik Indonesia tentang Standar Isi untuk Satuan Pendidikan Dasar dan Menengah. Jakarta: Depdiknas.

Hosnan. (2016). Pendekatan Saintifik dan Kontekstual Dalam Pembelajaran Abad 21. Bogor: Ghalia Indonesia.

Markaban. (2008). Model Penemuan Terbimbing pada Pembelajaran Matematika SMK. Yogyakarta: Departemen Pendidikan Nasional Pusat Pengembangan dan Penataran Guru Matematika.

Satyawati, Ni Nyoman Sri Budi. (2011). Pengaruh Model Pembelajaran Penemuan Terbimbing Berbasis LKS Terhadap Hasil Belajar Matematika Siswa Ditinjau dari Kecerdasan Logis Matematis pada Siswa Kelas X SMA N 1 Bangli. Jurnal Penelitian Pascasarjana Undiksha, (online), Vol. 2. No. 2, (https://pasca.undiksha.ac.id, diakses 19 Februari 2018).

Purwatiningsi, S. (2013). Penerapan metode penemuan terbimbing untuk meningkatkan hasil belajar siswa pada materi luas permukaan dan volume balok. Jurnal elektronik pendidikan matematika tadulako, Vol. 1(1), 2013.

Sugiyono. (2017). Statistika untuk Penelitian. Bandung: Alfabeta.

Wisnawati, dkk. (2014). Pengaruh Model Pembelajaran Penemuan Terbimbing Terhadap Kemampuan Memecahkan Masalah Matematika Siswa Kelas IV SD. e-Journal Mimbar PGSD Universitas Pendidikan Ganesha, (online), Vol. 2, No. 1, (https://ejournal.undiksha.ac.id, diakses 25 Januari 2018) 